REFLECTIONS:

NEUROLOGY AND

THE HUMANITIES

Section Editor

Anne W. McCammon,

MD, FAAN

\title{
Taking sides
}

"I'm ready to move forward with organ donation. Jim and I always talked about it, and I know we'd all feel better knowing that he was able to help other people. He always took care of his heart, he never smoked or drank, and his kidneys are healthy. Thinking about his heart giving someone else life gives me comfort; it will help me get through these next years. Can you please help me to get in touch with the organ donation people?"

I had to decide how to respond.

I empathized with Kathy's request, her desire to ensure that at least some positive outcome came out of her husband's death. His sudden traumatic brain injury, disrupting a lifetime of good health, had been a shock to the entire family, and I could see that Kathy was barely holding herself together in order to support her children. She was stoic in front of her family and the doctors, but I'd watched her through the glass panels of Jim's intensive care unit (ICU) room. Her grief bubbled to the surface then, when she thought no one was looking.

I looked at her tousled hair and tired eyes. A cup of stale coffee sat untasted at her side. The clothes that hung loosely on her frame were the same ones that she had been wearing at the time of Jim's admission 2 weeks ago, but they had fit her then. I realized that I hadn't seen her eat or sleep during his entire hospital stay. The calm, composed, and in-control woman who had walked into the hospital was gone, replaced by a desperate wife hoping to make good come out of the unthinkable.

The truth was this: Although Jim's brain injury was severe, he was not brain dead. His brainstem was intact, and he was breathing on his own. And, in some part because he had taken such good care of his heart and lungs for all those years, he would likely continue to breathe for hours, or even days after he was extubated, during which time his vital organs would become increasingly starved of oxygen. The odds that he would be a viable candidate for organ donation after cardiac death were miniscule. I recognized this after a few moments in the room with him, but the formal evaluation that would take place in order to come to the same conclusion would take hours or even days, during which Kathy and her family would remain suspended in limbo, hovering at the bedside of their unconscious loved one, exhausted but struggling to show their love in whatever ways they could. At the end of it, when he was rejected, there would be one more loss to face.

I wondered if Jim had truly made an informed decision when he expressed his willingness to be an organ donor in those informal discussions with his wife. The words ORGAN DONOR were written right there on his driver's license, literally in black and white. Did he just check off the box without a second thought? Did he really consider the implications of his decision? If he had seen the way his wife looked right now, and understood the impact his decision might have on her, would he have changed his mind? I would never know the answers to those questions. I wasn't sure it was even my place to ask them.

What about all of those who might benefit from Jim's decision, including the man in the next room? $\mathrm{He}$, along with half a dozen other patients in the ICU, had such poor cardiac function that they were too unstable to leave the hospital. Their lives, and those of their families, had been put on hold while they waited for heart transplants. There were plenty of others like them across the country. Was it worth adding so much stress to Kathy's next few days in order to hold on to the tiny chance that Jim's heart might save another's life? Even if things didn't work out, would she gain solace in the fact that we had tried?

I have had the words ORGAN DONOR written on my driver's license since I first had one. My 17-year-old self put them there because everyone else was doing it, because they were a status symbol, and because teenagers are immortal anyway. In no way did I make an informed decision, or consider the impact that the choice might have on my family. As I watched Kathy struggle, I thought about those words for the first time in a long time. I imagined my family gathered at my bedside. I wondered what they would do, how they would cope, and what choices they would make on my behalf.

All of this passed through my mind in the short space of time between Kathy's question and my

Listen to Dr. Glod read this story, available on the $\mathrm{iPad}^{\circledR}$ and Android ${ }^{\mathrm{TM}}$ devices. 
answer. I pictured the hours of fruitless waiting that lay ahead of both of us. I could tell her that Jim's heart was unlikely to save anyone. I could ask her if donating his skin and corneas would give her solace. I could remind myself that it was not my place to make this judgment, and make a referral for organ donation. Finally, I sat down at the bedside, took a deep breath, and said the only thing I could. 


\title{
Neurology
}

\author{
Taking sides \\ Susan A. Glod \\ Neurology 2016;86;e120-e121 \\ DOI 10.1212/WNL.0000000000002495
}

This information is current as of March 21, 2016

\section{Updated Information \& Services}

\section{Subspecialty Collections}

Permissions \& Licensing

Reprints including high resolution figures, can be found at: http://n.neurology.org/content/86/12/e120.full

This article, along with others on similar topics, appears in the following collection(s):

\section{Coma}

http://n.neurology.org/cgi/collection/coma

Critical care

http://n.neurology.org/cgi/collection/critical_care

Palliative care

http://n.neurology.org/cgi/collection/palliative_care

Prognosis

http://n.neurology.org/cgi/collection/prognosis

Information about reproducing this article in parts (figures,tables) or in its entirety can be found online at:

http://www.neurology.org/about/about_the_journal\#permissions

Information about ordering reprints can be found online:

http://n.neurology.org/subscribers/advertise

Neurology ${ }^{\circledR}$ is the official journal of the American Academy of Neurology. Published continuously since 1951, it is now a weekly with 48 issues per year. Copyright @ 2016 American Academy of Neurology. All rights reserved. Print ISSN: 0028-3878. Online ISSN: 1526-632X.

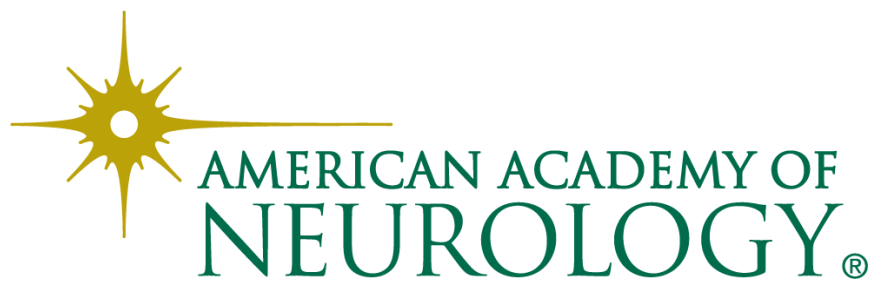

